\title{
IDENTITY POLITICS IN THE 2019 INDONESIAN GENERAL ELECTIONS: ITS SIGNIFICANCE AND LIMITATION
}

\author{
Djayadi Hanan \\ Lecturer of Political Science, International Relations Department, Paramadina University, \\ Jakarta - Indonesia; Executive Director of Indonesian Survey Institute (LSI) \\ E-mail: djayadi.hanan@paramadina.ac.id
}

\begin{abstract}
.
Identity politics was significant in 2019 Indonesian general elections. The result of the election however, seems to show that identity was only significant in presidential but not in legislative election. Given that the legislative and presidential elections are conducted concurrently, it is logical to assume that what is significant in the presidential election will also be significant for the legislative election. This paper tries to briefly answer several questions. Is identity politics really rising? Why does it seem to be significant only in the presidential and not the legislative election? If identity politics in the presidential election is important, assuming that the incumbent is mostly the target of that politics, why did the incumbent still win? What are the implications of this for Indonesian democracy? Data of the study were taken from the Saiful Mujani Research and Consulting (SMRC) and the Indonesian Survey Institute (LSI) surveys and exit poll. Theoretical guidance for the discussion will be mainly based on the voting behavior and identity politics literature. The study indicates that identity politics was rising and significantly in play during this election, including by using fake news. However, the impact of identity politics is limited by the fundamental factors (such as public evaluation on the incumbent), making it fail to be a deciding factor in presidential election. Importantly, the multipolar nature of competition in legislative election made identity politics difficult to exert decisive effect.
\end{abstract}

Key words: fake news; fundamental factors; identity politics

\begin{abstract}
ABSTRAK.
Politik identitas terlihat signifikan dalam Pemilu 2019 di Indonesia. Namun, dari hasil pemilu, ia hanya tampak signifikan di pemilu presiden, tidak di pemilu legislatif. Karena pemilu presiden dan legislatif dilaksanakan secara serentak, secara logika bisa diasumsikan apa yang signifikan dalam pemilu presiden akan signifikan juga dalam pemilu legislatif. Tulisan ini mencoba menjawab sejumlah pertanyaan. Benarkah penggunaan politik identitas meningkat? Mengapa ia hanya tampak signifikan dalam pemilu presiden dan tidak dalam pemilu legislatif? Bila politik identitas sangat penting, dengan asumsi yang menjadi targetnya adalah petahana, mengapa petahana masih keluar sebagai pemenang pemilu presiden? Apa saja implikasi hal ini terhadap demokrasi di Indonesia? Pembahasan dalam tulisan ini menggunakan sejumlah data, terutama survei nasional dan "exit poll"dari Saiful Mujani Research and Consulting (SMRC) dan dari Lembaga Survei Indonesia (LSI). Kerangka teoritis untuk pembahasan didasarkan terutama pada teori-teori perilaku memilih dan politik identitas. Penelitian ini menemukan bahwa politik identitas memang berperan signifikan, termasuk dengan cara menggunakan kabar palsu. Namun, dampak politik identitas dibatasi oleh faktor fundamental (seperti evaluasi pemilih terhadap kinerja petahana) sehingga tidak menjadi penentu hasil pemilu presiden. Karena sifat kompetisi di pemilu legislatif yang multipolar, politik identitas sulit untuk berperan signifikan.
\end{abstract}

Kata kunci: faktor fundamental; kabar palsu; politik identitas

\section{INTRODUCTION}

The result of the 2019 Indonesian presidential election seems to show the importance of identity, particularly religion and ethnicity, in determining the partisan choices of the voters. The official result from the Indonesian General Election Commission (KPU) shows that Joko Widodo (Jokowi) was outperformed by his opponent, Prabowo Subianto (Prabowo), in the areas where the so-called political Islam is strong.
Prabowo won, for instance, in the provinces of Aceh, West Sumatra, South Sumatra, West Java, Banten, South Sulawesi, South Kalimantan, and West Nusa Tenggara. On the other hand, Jokowi beat Prabowo in areas where Islam is considered more moderate or more pluralistic as well as in areas where the non-Muslim population is significant. For example, Jokowi won by a significant margin or landslide in the provinces of Lampung, Central Java, East Java, West Kalimantan, Central Kalimantan, North 
Sulawesi, East Nusa Tenggara, and Papua.

The result also shows that Jokowi won in the areas where Javanese ethnicity is predominant or significant. For example, in Sumatra, Jokowi won in North Sumatra and Lampung, two provinces which have significant Javanese populations. In Java, the Javanese are predominant in Central Java, East Java, and Yogyakarta, where Jokowi also won by landslides. On the other side, Prabowo carried West Java and Banten, where ethnic Sundanese are predominant, West Sumatra where the ethnic Minang are a majority, and Madura where the Madurese are the largest population.

First observations based on this result can lead to the impression that identity played an important role in the election. In other words, one could say that Indonesian voters are polarized along the lines of identity (religion and ethnicity) in the 2019 election. The more politically Islamic oriented and non-Javanese voters tended to vote for Prabowo while the less politically Islamic oriented and Javanese voters tended to vote for Jokowi.

This observation seems less clear, however, if we compare the presidential with the legislative election result. If political Islam was significantly in play, we should expect that political support for Islamic political parties should also be rising, or at least be higher than the previous election.

This is not the case, however. The total vote share for all Islamic parties is stagnant at the level of 30 percent, more or less. In the most recent previous elections (2009 and 2014), the total vote share for Islamic political parties is more or less the same. In addition, the vote share for other political parties is as fragmented as before. The vote share difference between the winner and the runner up is only about 6 percent, making it similar to the 2014 legislative election. The number of political parties which will be represented in parliament is now nine, only one party less than the 2014 legislative election result.

Given that the legislative and presidential elections are conducted concurrently, it is logical to assume that what is significant in the presidential election will also be significant for the legislative election. Identity politics, however, seems to be significant in the presidential but not the legislative election. Several questions are raised that need to be studied further. Is identity politics really rising? Why does it seem to be significant only in the presidential and not the legislative election? If identity politics in the presidential election is important, assuming that the incumbent is mostly the target of that politics, why did the incumbent still win? What are the implications of this for Indonesian democracy? This paper will answer, although briefly, these questions.

As summarized by Aspinall (2011), Fox and Menchik (2011), Mietzner (2019), Pepinsky et al. (2012), and Tanuwidjaja (2010), the importance of identity politics, particularly related to religion and ethnicity, in Indonesia, is widely acknowledged in the literature. Scholarship on this subject find that Indonesians are "devotedly religious and express their piety in diverse ways within social life" (Fox \& Menchik, 2011, p. 3). As a consequence, the expression of identity, particularly religion, can be found both in political competition and in public policies, at the national and local levels.

In electoral politics, at least until 2014, the role of identity politics, particularly Islam, is portrayed rather contradictive in the literature. On the one hand, particularly at the national level, Indonesian democracy is secularizing (Mujani \& Liddle, 2009; Pepinsky et al., 2012). In this context secular politicians and political parties dominate the competition. The evidence for this is compelling; since democratic election was introduced in Indonesia in 1999, the total vote share received by four major Islamic parties (PKS, PPP, PKB, and PAN) has been decreasing or stagnant at the level of $30 \%$. Comparing this result with the vote share of Islamic parties of the only democratic election before reformasi era (1955 election), the decrease of Islamic political parties' support is even more clear because at the time Islamic parties could gain almost $50 \%$ of the total national votes. On the other hand, researches on local electoral politics find that identity, religion in the large part and ethnicity to a certain degree, is one important variable that can determine electoral outcomes (Baswedan, 2007). The importance of religion, particularly Islam, in local electoral politics gets even more attention because of its decisiveness in determining the outcome of the 2017 Jakarta's gubernatorial election (Romli, 2019).

The analysis of the importance of identity politics in national electoral politics 
started to be more available since the election of 2014 and 2019, as in these two elections the issue of religion was played out widely by the contestants and supporters of the candidates in the elections (Fossati, 2019; Mietzner, 2019). Most of these analyses however, focus on the salience of identity namely how identity politics was played out and to what extent it is played out in electoral politics. This paper will contribute to this debate by adding an element of the decisiveness of identity politics in determining the result of election. This paper will add an argument that identity politics can be played out, but whether or not it will make the one who play it victorious or not depends on several factors such as fundamental factors and the context of the electoral competition.

The discussion will be based on data, particularly surveys and exit polls, which were conducted by the Saiful Mujani Research and Consulting (SMRC) and the Indonesian Survey Institute, the English term for Lembaga Survei Indonesia (LSI), during this national election cycle. Theoretical guidance for the discussion will be mainly based on the voting behavior and identity politics literature.

\section{METHOD}

Data of the present study were drawn from 18 national surveys conducted by SMRC between 2015 and 2019 and an exit poll of the 2019 Indonesian General Election conducted by SMRC and LSI. The sample size of the 18 national surveys was between 988 respondents (the smallest) and 2479 (the largest). Each sample in these national surveys was representative of the characteristics of Indonesian national voters' population. By law, Indonesian voter is defined as a person who has reached the age of 17 years old or has got married.

Each sample was taken from the population by using exactly the same methods of multistage random sampling. The process of sampling was as follows. The primary sampling unit of the surveys was village (desa/kelurahan). First, the villages at the level of provinces and or electoral districts were randomly selected proportionally. Second, in each of the village selected, five neighborhood association (RT) were randomly selected. Third, in each selected
RT, two households were randomly selected. Finally, from each of the household one respondent (male/female) was selected. If from one household the female was selected, from the next household one male respondent was selected. The respondent was interviewed face to face by a trained surveyor. Certain questions in the surveys were the same from one survey to another, especially about public evaluation on government performance, on general condition such as economy, politics, security, democracy, etc., and in our case also about identity politics.

Exit poll is actually a kind of survey with the same method. The difference is that the primary sampling unit is not the village but the polling station (TPS). Exit poll is a method of survey by asking questions to a person who just gets out of a polling station. SMRC and LSI conducted an exit poll during the day of election of April 17, 2019. The sample size was 3000 TPS, randomly selected from 813.350 total TPS across the country. The TPS were first grouped based on national electoral districts for national parliament (DPR) and also based on rural and urban divide. From each of these electoral districts, the TPS were randomly selected proportionally until the number reach 3000 TPS. From each TPS, one respondent was selected randomly based on the timing he/she got out of the TPS. The selected respondent was then interviewed by a trained surveyor face to face. In an exit poll, the questions were mainly about the reasons of why voters voted the way they did.

\section{FINDINGS AND DISCUSSION}

This section shows and discusses the findings of the study with regard to identity politics, and fundamental factors and the salience of identity as well as its limitation.

\section{Is Identity Politics Rising?}

In this paper identity politics is understood as the utilization of identity as "...a useful tool for mobilizing people, policing boundaries, and building coalitions that can be deployed in the struggle for power..." (Eifert et al., 2010, p. 494). In other words, identity politics is the utilization of any identity by persons or groups against their opponents in the efforts of winning the political power competition like in elections. Two types of 
identity - ethnicity and religion - are among the most powerful motivators of political behavior, making them very important in identity politics (Abranjo, et al., 2001; Berman \& Laitin, 2008; Varshney, 2002; Wilkinson, 2004).

An exit poll result describes Indonesian voters as polarized along religious and ethnic lines when the question is about presidential choice. This is in line with the observation offered at the beginning of this paper. The following table describes this in more detail.

Table 1. 2019 Presidential Support Based on Identity and Religious Organization

\begin{tabular}{|c|c|c|}
\hline Category & $\begin{array}{c}\text { Jokowi - Amin } \\
(\%) \\
\end{array}$ & $\begin{array}{c}\text { Prabowo - Sandi } \\
(\%)\end{array}$ \\
\hline \multicolumn{3}{|l|}{ Ethnicity } \\
\hline Javanese & 67 & 33 \\
\hline Sundanese & 36 & 64 \\
\hline Batak & 65 & 35 \\
\hline Minang & 10 & 90 \\
\hline Betawi & 32 & 68 \\
\hline Madurese & 42 & 58 \\
\hline Buginese & 46 & 54 \\
\hline \multicolumn{3}{|l|}{ Religion } \\
\hline Muslim & 50 & 50 \\
\hline Christian & 96 & 4 \\
\hline Others & 98 & 2 \\
\hline \multicolumn{3}{|l|}{$\begin{array}{c}\text { Religious } \\
\text { Organization }\end{array}$} \\
\hline NU & 60 & 40 \\
\hline Muhammadiyah & 35 & 65 \\
\hline Others & 30 & 70 \\
\hline
\end{tabular}

Source: SMRC \& LSI Exit Poll, April 2019

The connection between ethnicity and presidential choice is shown clearly. The data in table 1 above show that a strong majority of Javanese (67\%) voted for Jokowi, while only $33 \%$ chose Prabowo. The support from the Javanese ethnic group is the most important in this regard because this ethnic group makes up more than $40 \%$ of the total Indonesian population. On the other hand, among the second largest ethnic group, Sundanese, support is overwhelmingly for Prabowo (64\%), with only 36\% for Jokowi. Because the Sundanese are only about $16 \%$ of the population, however, this big win does not make up for Prabowo's loss to Jokowi among the Javanese. I
Jokowi was also supported overwhelmingly by the Batak ethnic group (65\%) compared to Prabowo (35\%). Meanwhile, Prabowo was supported also with a strong majority by the Minang (90\%), Betawi (68\%), Madurese (58\%), and Buginese (54\%) ethnic groups. Simply put, the Javanese were for Jokowi, while the non-Javanese, except for the Bataks, were for Prabowo in the 2019 presidential election.

Similar polarization can be seen along religious lines through this exit poll. About 96\% of the Protestants and Catholics voted for Jokowi. Similarly, about $98 \%$ of the other non-Muslim groups also voted for Jokowi. In other words, non-Muslims were for Jokowi. Among the Muslim group, the vote was evenly distributed, $50 \%$ for Jokowi and 50\% for Prabowo. There was seemingly no polarization based on these numbers.

However, when we narrow down the categorization among Muslims, we can see a similar pattern of polarization. Indonesian Muslims can also be categorized based on their affiliation with Islamic movement organizations such as Muhammadiyah, Nahdlatul Ulama (NU), Persatuan Islam(Persis), etc. Jokowiwas supported overwhelmingly by NU-affiliated Muslims (60\%) compared to Prabowo (40\%). But the nonNU affiliated Muslims were overwhelmingly for Jokowi's opponent. Prabowo was supported by $65 \%$ of Muhammadiyah members and $70 \%$ of other Islamic organization members.

NU-affiliated Muslims are the largest group among Indonesian Muslims. According to SMRC's national survey of November 2016, this group makes up about $50 \%$ of Indonesian Muslims. In general, NU-affiliated Muslims are considered more attached to Indonesian traditional ways of life (and called traditionalists) and are less political. Sometimes, their Islamic religious value and practice are considered more relaxed. On the other hand, the non-NU affiliated Muslims, like Muhammadiyah and others, tend to be more modernist in their religiosity and are usually more attached to political Islam. In other words, less politically Islamic groups were for Jokowi, while more politically Islamic groups were for Prabowo.

These categories of religious and ethnic lines are overlapping. NU affiliated Muslims are overwhelmingly Javanese while non-NU affiliated Muslims are overwhelmingly non- 
Javanese. This identity polarization is a good indicator that identity politics is actually in play in the election.

The narratives and issues in the election campaign provide clues about the utilization of identity-related issues to portray one candidate as closer or not closer to a given identity and the other candidate on the opposing side. The data from the same exit poll mentioned above also describes this clearly.

One issue is about Jokowi as a communist. This issue can be connected to identity because communist is equal to atheist in Indonesia. An atheist must be against religion, particularly Islam. This issue has been in public actually since the election of 2014, when Jokowi was running for his first term. Up to April 2019, the data show that almost half of the Indonesian electorate $(44 \%)$ was exposed to this issue (SMRC, 2019). This means that this issue has been widely reported and is well known to the public.

Another related issue is that Jokowi is a Chinese puppet. The identity element of this issue is clear. Portraying Jokowi as not only friendly to but also working for the Chinese will clearly put him on the opposing side of the Indonesian public in general, given that the Chinese minority is sometimes in a tense relationship with other groups. Up to April 2019, this issue has been widely known by about $36 \%$ of the electorate.

The third most relevant issue is that Jokowi is anti-Islam. In April 2019, about 34\% of the electorate was exposed to this narrative. From the identity politics perspective, those three issues are connected and strengthen each other in an effort to portray Jokowi as a candidate who is on the opposing side and even a threat to the Indonesian public whose identity is predominantly religious and particularly Muslim.

Do these electoral phenomena of identity politics have a deeper basis in Indonesian society in general? Longitudinal survey data from five national surveys in the period of 2017-2019 (SMRC, 2017, 2018, 2019, in press) confirm that they do. The mobilization of identity for political purposes, particularly religion, will not have resonance in the public if there is no belief that it is important (Fearon, 2006; Hatina, 2007; Nicholson, 2008; Parekh, 2008).

One way to look at this is by examining the level of people's willingness or tolerance for the possibility of being led (in public life) by a leader whose religion is from a minority group. SMRC and LSI have longitudinal data about the so-called "anti-non-Muslim leader" sentiment among the Muslim group. In general, the findings show that there is an increase in this sentiment, especially since Jokowi ran for president in the previous election.

In a national survey of April 2019 (SMRC, 2019), it was found that a majority of the Indonesian electorate (52\%) believe that Muslims may not be led by a non-Muslim (as mayor, district head, governor, vice president, president). This number is higher than the finding from May 2017 (46\%). Relating this to the 2019 presidential election, this sentiment was highest among Muslims (57\%) and in the areas where Prabowo won the race such as Sumatra (58\%), West Java (68\%), and Banten (67\%). The sentiment was lower in the areas where Jokowi won the race such as East Java (43\%), Kalimantan (41\%), Bali and Nusa Tenggara (31\%), or Maluku and Papua (21\%). Similarly, the sentiment was higher among ethnic groups that supported Prabowo and lower among ethnic groups that supported Jokowi.

Looking at this sentiment more closely among Muslim voters and also with more specific levels of leadership (mayor, governor, vice president, president), the data show three patterns. First, there is an increase of this sentiment for all levels of leadership. Second, the higher the level of office of leadership, the higher the sentiment. Third, specific to the presidential office, this sentiment was always high at 50\% or more, even during the time when sentiment against other levels of leadership was low.

The sentiment against non-Muslim mayors/ heads of districts was very low in January 2008 (41\%). 46\% said they did not mind if a nonMuslim becomes mayor or district head. This sentiment was even lower in March 2016 (39\%). But starting from November 2016 until August 2017 , it rose to $50 \%$, and became even higher after that. In April 2019, the sentiment was high at $58 \%$.

A similar pattern also applies to the sentiment against non-Muslim governors. That sentiment was low at $42 \%$ in January 2008, but high at $60 \%$ in April 2019. The sentiment against a non-Muslim vice president was also low in March 2016 (41\%), but high at 62\% in April 
2019. Even higher is the sentiment against a nonMuslim president. It was at the level of $48 \%$ in January 2008. But starting from November 2016 this sentiment rose to $60 \%$ on average, reaching the highest level in April 2019 (66\%).

The increase of this anti-non-Muslim leader sentiment provide more fertile ground for the rise of identity politics. The fact, as far as the data goes, that there are similar patterns of the distribution of partisan choice with the distribution of identity and the rise of anti-nonMuslim leaders, is a clear indication that identity politics is rising and played an important role in the last presidential election.

Given that the2019election wasa concurrent election, this raises the question of why identity politics does not seem to be clearly reflected in the legislative election. The best indicator for the rise of identity politics, particularly related to Islam, in a legislative election, should be the increase of partisan support for Islamic political parties. The total partisan support for five Islamic parties which competed in the election is only about 30\%, however. This number has not changed significantly since the election of 2004. It has been stagnant during the last fifteen years of democratized Indonesia.

One way to understand this is by looking at how identity politics can play an important role in a competition like an election. Identity, particularly religion and ethnicity, can be a powerful motivator or driver of social and political behavior (Bowles \& Gintis, 2004; Hechter, 1978; Humphreys, 2008). To enable it to become a significant tool in a political competition like an election, however, at least two conditions have to be present (Eifert, et al., 2010).

First, that the identity in question is perceived to be at stake. There is a widespread feeling, for instance, that one identity is threatened by another to the extent that a certain identity can suffer great loss through political competition. The election itself is often viewed as an arena where identity is at stake. Clear polarization between two competitors in head to head (bipolar competition) elections can also be considered as a situation that puts identity at stake. The second condition is that the competition or election is competitive or closely fought. The winner can only be winning by a small margin against the opponent.
In the Indonesian case, the presence of these two conditions was weaker in the legislative election and relatively stronger in the presidential election of 2019. Unlike the presidential election, the competition in the legislative election was multipolar, not bipolar (head to head). In this kind of competition, it is difficult to portray one or more political parties as being for one religion while others are not. It would be even more difficult to portray more than twenty thousand legislative candidates as being for one identity or another. The sense of specific identities being threatened was relatively absent.

As described in the data on sentiment against non-Muslim leaders above, the higher the office and the fewer the number of offices available, the higher the level of sentiment. This implies that the stakes are higher in the competition for higher and fewer offices. In the case of the presidential office, the stakes are the highest. Legislative seats are clearly not the highest office. In addition, legislative seats are abundant. In every legislative election, the number of seats that are up for grabs is more than twenty thousand in total at all levels of municipality/ district, province, and the national legislature. In other words, the sense of identity being at stake is not as strong in the legislative election. Similarly, the sense of a very competitive and close election was also not there. Thus, identity seems not to be significantly in play here.

The comparatively less significant importance of identity in the legislative than the presidential election also implies that identity politics was more related to the heated rivalry or deep polarization between Jokowi and Prabowo. This means that even if the context is similar, if the competition is not between these two, the state of the race could be different.

\section{Fundamental Factors and the Salience of Identity: Why Does the Incumbent Still Win?}

If identity was rising and was significantly in play in the 2019 presidential election, how then could Jokowi pull it off and end the race a winner? Can fundamental factors and incumbency explain the victory of Jokowi?

One could say that even if there is a strong incumbent, identity politics could be the winning factor for whoever utilizes it. The well-known example of this is the Jakarta gubernatorial election of February and April of 2017. The 
strong incumbent was decisively defeated by the contender who directly or indirectly utilized identity politics along religious and ethnic lines.

Both identity and fundamental factors are considered important by voting behavior theorists in explaining partisan choice in elections (Dowding, 2018; Evans \& Northmore-Ball, 2018; Hutchings \& Jefferson, 2018; Mujani et al., 2011; Mujani et al., 2018). Incumbency (presidential approval ratings), general economic condition, general security condition, and government performance in various sectors of public life, are among important fundamental factors that can determine the likelihood of an incumbent to get reelected. Sociological factors can also be important because voters can be motivated by their religion, ethnicity, class, etc. to make a decision as to who they are going to vote for in an election.

The literature on voting behavior in general suggests that fundamental factors are the most powerful predictors of the election whenever an incumbent is running for re-election. When fundamental factors are good or positive, the voters tend to re-elect the incumbent. When the fundamental factors are negative, the incumbent will face difficulties and potentially lose to the contender. Identity politics, as mentioned above, however, can be a challenge even if the incumbent enjoys good fundamentals.

The two conditions that can enable identity politics to play out significantly (Eifert, et al., 2010) seem to be present in the presidential election. First, the competition was head to head, thus, competitive and polarized. The polarization had been there since 2014 because 2019 was actually a rematch between the two candidates. Second, the competition is for the highest office in the country, so the stakes are high. This resonated with the phenomenon of high sentiment regarding anti-non-Muslim leaders as mentioned above.

But the second condition was not clearly present, that is the widespread feeling that identity, in this circumstance, Islam, was under threat. This condition will usually be automatically there when a candidate from one identity is facing a candidate from the opposing identity. In the Indonesian context this should be a Muslim versus a non-Muslim candidate. In the 2019 presidential election this was not the case. Both candidates were Muslim and therefore there was no objective or direct evidence that Islam was in danger when the incumbent was reelected. It would be much easier for the opponent of Jokowi to say that he was the threat to Islam if he was non-Muslim. His religious identity was not synchronous with the narrative against him.

Butidentity can be constructed or manipulated (Habyarimana, et al., 2007; Posner, 2004). Through social manipulation or construction, person or group can be portrayed (by themselves or by others) as part of certain identity despite the fact that the person or group is actually not part of that certain identity. Here the role of hoaxes and fake news is important. Three main fake news items or hoaxes mentioned above (Jokowi is the puppet of China, Jokowi is a communist, and Jokowi is anti-Islam) are wide-spread and known to the public. These three fake news items are clearly part of an effort to create or construct a new identity for Jokowi, namely that he is a threat to Muslims and Islam.

In fact, hoaxes and fake news are widespread phenomena during this election cycle. The Ministry of Communication and Information (KOMINFO) of the Republic of Indonesia in its report stated that from August 2018 through June 2019 there were 2,370 hoaxes or fake news items circulated among the public (Kominfo, 2018, 2019, in press). During the months approaching the election, the number of fake news items was the highest. The peak was in March, April, and May of 2019 with the number of fake news items at 453, 501, and 402 consecutively.

The largest number of fake news items are about politics (753), followed by government issues (268), health issues (254), and religion (118). Many of these fake news items were related to identity issues. To provide a few examples, here are some identity-related fake news items, as reported by KOMINFO:
"Jokowi made official the use of a Jesus Christ statue in Toraja"
"Teten Masduki confirmed that the presidential staff office was often used for PKI meetings as instructed by Jokowi"
"Jokowi: "PKI is not guilty and not a threat; radical Islam is the threat!"
"Advisors in the presidential palace are members of the Chinese Communist Party"
"So, now you know that Jokowi's regime is anti-Islam" 
"Viral!! Thousands of Chinese foreign workers finally revealed themselves to the public"

"Ahok will be the vice president, then president"

"Police chief: PKI is not a threat to the state compared to Islam"

"Revealed: Jokowi's original name was Herbertus Handoko Joko Widodo bin Oey Hong Liong"

"Fact: the current president is actually a Christian. And the current government is controlled by Christians"

The examples above are only a few of the many fake news items distributed among the public through mainly social media and non-mainstream online media. The bottom line was clear: it was a massive effort to portray the incumbent as anti-Islam, a communist, and the puppet of China. The combination of these three elements is enough to portray the incumbent as someone whose identity is a threat to a majority of Indonesians.

Was there fake news about Jokowi's opponent or Prabowo? Yes, there was. However, the numbers seem very low compared to the fake news about the incumbent. For example, there was fake news that stated: "Prabowo is a worshipper of the tomb" (meaning not a pure Muslim). In other words, fake news seemed to target mainly Jokowi both as president as well as candidate.

The effectiveness of fake news in constructing fake identity for the incumbent depended very much on the extent to which that information was believed by the public. Public opinion data found that the influence of this fake news on the public is limited. It was widely heard but only a few believed it was true. From the exit polls mentioned above, among the 44\% of the public who were exposed to the issue that Jokowi was a member of the Indonesian Communist Party (PKI), only $18 \%$ believed it and $70 \%$ did not believe. Among $36 \%$ of the members of the public who were exposed to the issue that Jokowi is the puppet of China, only $32 \%$ believed it. Similarly, $34 \%$ of the public was aware of the issue that Jokowi is anti-Islam, but only $18 \%$ of this $34 \%$ believed that it is true.

The level of influence of identity-related fake news, especially about the incumbent, has been stagnant at this low level during Jokowi's presidency. From nine national surveys conducted by SMRC between September 2017 and April 2019 (before election day), members of the public who believe that Jokowi is a communist was stagnant at $5-6 \%$, while only between 3-6\% believe that Jokowi is anti-Islam. A slightly higher number of voters believe that Jokowi is a Chinese puppet, but that number is also stagnant at the level of 6-13\%.

This data description leads us to say that the use of identity related issues, particularly the ones distributed by using fake news, although having some effect, has been limited in its role in making identity, particularly religion, a factor that was at stake in this election. Identity was salient, but not to the extent that it became the most important deciding factor.

Other than the non-existence of two opposing identities, several other factors also possibly limit the influence of fake identity news. One is the fact that the electorate has been much more familiar with the incumbent compared to the 2014 election. Jokowi was not as mysterious as in 2014 when he was still nobody not only among members of the public but also among the national political elites. It would be more difficult to promote successfully falsehoods about somebody when he/she is widely known.

Another factor could be the choice of Jokowi's running mate: Ma'ruf Amin. He is wellknown as a very senior and respected Islamic scholar who has been leading the Indonesian Ulama Council(MUI), the umbrella organization for Islamic scholars nationally. Ma'ruf Amin is also known as an important leader of the NU organization. His view of Islam is considered conservative making him also friendly to more conservative Muslim voters. His selection was mainly regarded as a way to provide a protective cover for Jokowi against identity-based attacks from those more politically Islamic groups which were attached to Jokowi's contender. This strategy seemed to work since it would have been very difficult, for instance, to label Jokowi as anti-Islam while his running mate is the chief of the ulama (Islamic scholars).

When other important factors such as identity are not dominant, voting behavior theory states that fundamental factors should be considered when an election involves an incumbent. All these factors during Jokowi's 
administration were at least not against him, if not working in his favor.

In SMRC's national tracking surveys during the last three years of Jokowi's presidency since June 2016 until one week before the election, his approval ratings have been stable at the level of above $60 \%$ to $70 \%$. For comparison, with a similar level of approval ratings, the previous president, Susilo Bambang Yudhoyono (SBY), won by more than $60 \%$ of the vote in his reelection bid in 2009. Consistent with his approval ratings, people were also confident that Jokowi has the leadership skills to bring Indonesia to a higher quality of life. On average, about $70 \%$ of the public trust his leadership capacity.

Other fundamental factors, particularly the economy and security, were also evaluated positively by the public. The number of voters who regarded the economy as better than last year has always been higher than those who said that the economy was worse than last year. This positive evaluation has been stable since December 2015. This positive economy evaluation was consistent with the low level of inflation until April 2019. Low level of inflation has been also consistently translated into positive evaluations of the economy.

The same applies to security evaluation. People's evaluation of their security condition has been very positive since September 2005, including during all the years of Jokowi's presidency up to election day. With the exception of several aspects of daily life, people's evaluations of government performance in various sectors were also mostly positive. The most positive were evaluations of infrastructure, education, and healthcare. But the public's evaluation of several aspects of daily life such as job creation, the price of nine basic goods, and unemployment was neither positive nor negative. Nevertheless, all in all, people felt very good about the incumbent across various sectors of government programs.

In short, the less-effective utilization of identity politics, coupled with strong incumbency and positive fundamental factors have together enabled Jokowi to be victorious despite the fact that the competition had been not only competitive but also polarized/divisive. This is reflected in the voters' main reasons to support the incumbent or the contender. According to exit polls mentioned above, the incumbent's performance as shown by his programs became the main reason to vote for him ( $46 \%)$, followed by family choice (14\%), because he is close to and fights for the people (19\%), and his campaign advertisements and attractiveness (9\%). Similarly, the program promises became the main reasons for Prabowo's voters to support him (40\%), followed by family choice $(15 \%)$, campaign attractiveness $(12 \%)$, and he fights for the people $(8 \%)$. There is a significant number of voters who supported him because of religion (7\%), compared to Jokowi (2\%), a clue that identity politics was also in play.

\section{CONCLUSION}

This analysis shows that the utilization of identity, particularly ethnicity and religion, was widespread in 2019 Indonesian general election. This is possible and attractive to political players because the sentiment of identity politics among the voters has been rising during the last five years leading up to the election, as confirmed by the surveys data (both from SMRC and LSI). The use of identity politics in this election was also facilitated by the very competitive (closely fought and head to head competition) nature of presidential election. However, identity politics was not significantly in play in legislative election because of the multipolar nature of that election. In multipolar competition, it is difficult to play one identity against another.

Although identity politics was widely used in presidential election, its effect has been limited by two factors. First, fundamental factors such as incumbent's approval ratings and public evaluation on economy and incumbent's performance, were all in favor of the incumbent. Second, there was no clear identity different between the incumbent and his opponent, because both of them are more or less from the same religious and ethnicity backgrounds, making it difficult to convince enough voters that one candidate is the threat to certain identity. These two factors made the effect of identity politics was limited and difficult to be a decisive factor in the election.

How is the phenomenon of identity politics in 2019 Indonesian elections affected or connected to the state of democracy in the country? Indonesian commitment and support (preference) for democracy in general has always been at the 
level of moderate to high, amidst the signals of the rise of identity politics as described above.

The trend of this preference has been rising, especially during Jokowi's presidency. SMRC's national survey of April 2019 found that $78 \%$ of the public regard democracy as the best political system for the country compared to others. This number is higher than in June 2015 when Jokowi was still in his first year, and also higher than in June 2012 (56\%), before Jokowi ran for the presidency.

This trend is similar to the trend in people's satisfaction with the practice of democracy. In general, satisfaction with the practice of democracy is influenced by governmental performance in the economy, security, political stability, and law enforcement. Since the beginning of Jokowi's presidency, there has been a trend that people's satisfaction with the practice of democracy is rising. In October 2014, for instance, this satisfaction was at the level of $60 \%$, increasing to $65 \%$, and then $74 \%$ in various national tracking surveys from 2014 through April 2019 (SMRC, 2019).

In other words, there are indications that democracy and the practice of democracy are getting stronger in the eyes of the Indonesian public. Interestingly, perhaps unfortunately, however, as displayed by evidence from the 2019 general election, this increasing preference for democracy is coupled with increasing political intolerance. This is indicated by the increase in sentiment against non-Muslim leaders among Muslims as discussed in the previous section. As the increase of political intolerance can be a fertile ground for identity politics, we could say that Indonesian democracy in the near future is prone to the challenge of religious and ethnic politics or identity politics in general.

The survey results and analysis discussed above also imply that the identity politics challenge is clear and can be salient or break through under certain conditions. Hopefully, however, this challenge can still be managed successfully as long as the general conditions of the economy, political stability, security, and people's daily lives are still positive. Since the ground for identity politics is fertile, the challenge for Indonesians is how to avoid or prevent the two conditions that place identity politics in play: head to head competition and the widespread feeling that an identity is under threat. There must be more effort or even government policies adopted to prevent the widespread feeling or narrative that one's religion and/or ethnicity is under threat from another identity.

\section{REFERENCES}

Abranjo, M. A., Nagler, J., \& Alvarez, R. M. (2001). A natural experiment of racebased and issue voting: The 2001 city of Los Angeles elections. Political Research Quarterly, 58(2), 203-218.

Aspinall, E. (2011). Democratization and ethnic politics in Indonesia: Nine theses. Journal of East Asian Studies, 11, 289-319.

Baswedan, A. R. (2007). Regional autonomy and patterns of democracy in Indonesia [Unpublished Doctoral Dissertation]. Northern Illinois University.

Berman, E., \& Laitin, D. (2008). Religion, terrorism and public goods: Testing the club model. Journal of Public Economics, 92, 1942-1967.

Bowles, S., \& Gintis, H. (2004). Persistent parochialism: Trust and exclusion in ethnic networks. Journal of Economic Behavior and Organization, 55, 1-23.

Dowding, K. (2018). Rational choice theory and voting. In J. Fisher et al. (Eds.). The Routledge handbook of elections, voting behavior and public opinion (pp. 30-40). Routledge.

Eifert, B., Miguel, E., \& Posner, D. N. (2010). Political competition and ethnic identification in Africa. American Journal of Political Science, 54(2), 494 - 510.

Evans, G., \& Northmore-Ball, K. (2018). Long-term factors: Class and religious cleavages. In J. Fisher et al. (Eds.). The Routledge handbook of elections, voting behavior and public opinion (pp. 123135). Routledge.

Fearon, J. D., (2006). Ethnic mobilization and ethnic violence," in B. R. Weingast \& D. A. Wittman (Eds.). The Oxford handbook of political economy (pp. 852-868). Oxford: Oxford University Press.

Fossati, D. (2019). The resurgence of ideology in Indonesia: Political Islam, aliran and 
political behaviour. Journal of Current Southeast Asian Affairs, 38(2), 119-148

Fox, C. A., \& Menchik, J. (2011). The politics of identity in Indonesia: Results from political campaign advertisements. Paper presented at the APSA 2011 Annual Meeting Paper, Seattle, 2011 March 31April 3, Seattle.

Habyarimana, J., Posner, D., Humphrey, M., \& Weinstein, J. W. (2007). Placing and passing: Evidence from Uganda on ethnic identification and ethnic deception. Paper presented at APSA Annual Meeting. Chicago, 2007.

Hatina, M. (2007). Identity politics in the Middle East: Liberal thought and Islamic challenge in Egypt. New York, NY: Tauris Academic Studies.

Hechter, M. (1978). Group formation and the cultural division of labor," American Journal of Sociology, 84(2), 293-318.

Humphreys, M. (2008). Coalitions. Annual Review of Political Science, 11, 351-386.

Hutchings, V. L., \& Jefferson, H. J. (2018). The sociological and social-psychological approach. In J. Fisher et al. (Eds.). The Routledge handbook of elections, voting behavior and public opinion (pp. 21-29). Routledge.

KOMINFO (2018, August 1 - 2019, June 30). Laporan Isu Hoaks. https://www.kominfo. go.id

Mietzner, M. (2019) Authoritarian innovations in Indonesia: electoral narrowing, identity politics and executive illiberalism. Democratization, 26, 1-16.

Mujani, S., \& Liddle, R. W. (2009). Muslim Indonesia's secular democracy. Asian Survey, 49(4), 575-590.

Mujani, S., Liddle, R. W., \& Ambardi. K. (2011). Kuasa rakyat: Analisis tentang perilaku memilih dalam pemilihan legislatif dan presiden Indonesia pasca orde baru. Jakarta: Mizan.
Mujani, S., Liddle, R. W., \& Ambardi. K. (2018). Voting behavior in Indonesia since democratization: Critical democrats. Cambridge: Cambridge University Press.

Nicholson, L. (2008). Identity before identity politics. Cambridge: Cambridge University Press.

Parekh, B. (2008). A new politics of identity: Political principles for an independent world. New York: Palgrave Macmillan.

Pepinsky, T., Liddle, R. W., \& Mujani, S. (2012). Testing Islam's political advantage:Evidence from Indonesia." American Journal of Political Science. 56(3), 584-600.

Posner, D. (2004). The implications of constructivism for studying the relationship between ethnic diversity and economic growth. Paper presented at APSA Annual Meeting. September 2-5, 2004.

Romli, L. (2019). Political Identity and challenges for democracy consolidation in Indonesia. Politik Indonesia: Indonesian Political Science Review, 4(1), 78-98.

SMRC \& LSI (2019). Laporan exit poll pemilu 2019.

SMRC (2015). Laporan survei nasional

SMRC (2016). Laporan survei nasional

SMRC (2017). Laporan survei nasional

SMRC (2018). Laporan survei nasional

SMRC (2019). Laporan survei nasional

Tanuwidjaja, S. (2010). Political Islam and Islamic parties in Indonesia: Critically assessing the evidence of Islam's political decline. Contemporary Southeast Asia A Journal of International and Strategic Affairs, 32(1), 29-49

Varshney, A. (2002). Ethnic conflict and civiclLife: Hindus and Muslims in India. New Haven: Yale University Press.

Wilkinson, S. I. (2004). Votes and violence: Electoral competition and ethnic riots in India. Cambridge: Cambridge University Press. 